Article

\title{
Effects of Conditional Cash Transfers (CCT) in Anti-Poverty Programs. An Empirical Approach with Panel Data for the Mexican Case of PROSPERA-Oportunidades (2002-2012)
}

\author{
Odra Angélica Saucedo Delgado *, Vivian Kadelbach and Leovardo Mata Mata \\ Faculty of Economics and Business, University Anáhuac, Huixquilucan 52786, Mexico; \\ vivian.kadelbach@anahuac.mx (V.K.); leovardo.mata@anahuac.mx (L.M.M.) \\ * Correspondence: odra.saucedo@anahuac.mx; Tel.: +52(55)-5627-0210
}

Received: 23 October 2017; Accepted: 2 April 2018; Published: 1 May 2018

\begin{abstract}
Conditional Cash Transfer Programs (CCT) have been implemented in México and Latin America since the late 1990's. This type of program focuses on providing social government services by way of direct cash transfers to poor families that are often conditioned to the use of public education and health services. Despite the apparent short-term success of these CCT programs in the Latin American context, there still is much debate about whether CCT programs are effective in alleviating poverty. This paper analyzes the effectiveness of conditional cash transfer programs as a long-term incentive in the use of public services-health and education-among beneficiary families of PROSPERA-Oportunidades in Mexico. The Average Effect of Treatment on the Treated (ATT) for the time period 2002-2012 is estimated based on data from the Mexican Family Life Survey (MxFLS) using Propensity Score Matching (PSM). The results show that the program's impact on the use of preventive health and education services by poor families cannot be sustained in the long-term, which puts in doubt the effectiveness of this social protection intervention program in combating poverty in Mexico.
\end{abstract}

Keywords: poverty; conditionality; social protection; panel data analysis; Sustainable Development Goals (SDGs)

\section{Introduction}

Poverty is a multidimensional phenomenon and is not always limited to a lack of income. Hence, families and their members can suffer from multiple deprivations, such as poor health and malnutrition, little schooling or access to poor quality job opportunities at the same time (Alkire et al. 2015). On a global scale, there are still too many people living in extreme poverty today with an income below US $\$ 1.90$ a day who are confronted with the challenge of satisfying even the most basic needs. Despite the fact that extreme poverty has decreased by more than 50\% from 1990 to 2015, moving from 1900 to 836 million people, global poverty levels are still high. Therefore, eliminating poverty in all its forms remains one of the main challenges that countries worldwide are confronted with. This is why the first Sustainable Development Goal (SDG) ("Goal 1: End poverty") is the first one of the seventeen Sustainable Development Goals that were agreed to and signed by more than 150 countries in the year 2015 with the objective of reaching the defined goals by 2030 (UN 2015).

Governments worldwide have been designing social protection interventions focused on attending poverty issues over the past decades. An example is the Conditional Cash Transfer (CCT) program that was created and implemented by governments in multiple countries of Africa and Latin America with an innovative, multidimensional focus to combat poverty in a single government 
intervention. This type of program provides social government services to poor families by way of direct cash transfers that are linked to certain conditions related to the use of public education and health services.

There is much debate about CCT programs as anti-poverty programs. One of the key arguments in favor of these programs is based on the long-term modification of the use of related health and education services by participating families. de Brauw and Hoddinott (2011) argue that, based on the understanding that conditionality induces changes on poor families' behavior that lead to desirable outcomes, these programs should become a permanent feature of social protection in developing countries.

However, CCT programs have also been subject to criticism due to their narrow and short-term vision of how families overcome poverty. In addition, Standing (2007, 2008) and van Parijs and Vanderborght (2017) claim that these programs strengthen paternalistic notions of welfare-dependent schemes rather than sustainable economic rights. Their argument is based on the fact that families have to commit to attending health services and sending their children to school to receive the program's cash transfer benefits in return. Instead of making their own choices, families are thus forced to behave in a way that the government determines to be favourable for their human development and in turn for their escape from poverty.

Short-term evaluations made for these programs, especially PROSPERA-Oportunidades which has been in operation in Mexico since the late 1990's, provide evidence of their positive impact related to the development of capabilities among the beneficiary families (Escobar and González de la Rocha 2009; Largaespada 2006; Valencia 2008). Despite the apparent short-term success of these CCT programs not only in Mexico but in other Latin American countries there still is much debate about the state's paternalistic top-down interpretation of the poor's needs and its long-term effects (Farrington and Slater 2006; Hall 2008; Handa and Davis 2006; Vizcarra 2002; Molyneux 2006).

There is a growing body of evidence on short-term effects of conditional cash transfer programs on the use of public health and education services by poor families. Yet, a longitudinal analysis with panel data has not yet been carried out for these antipoverty programmes. This research aims to fill this gap in the current debate.

Therefore, the main goal of this paper is to analyze the effectiveness of the CCT programs as a long-term incentive for the use of public services - in health and education-among beneficiaries of PROSPERA-Oportunidades. We use panel data from the MxFLS (Mexican Family Life Survey), collected in 2002, 2005-2006, and 2009-2012 for the empirical analysis (UIA, CIDE, Duke University 2016).

The structure of this document consists of six parts: the second part briefly describes the conceptual design of the PROSPERA-Oportunidades program. In part three, the main short-term program achievements are presented. The fourth part discusses the problem of conditionality. The fifth describes the MxFLS survey, while the sixth part presents the estimations and results of the statistical analysis and closes with conclusions and some further comments.

\section{PROSPERA-Oportunidades: The Example of a Conditional Cash Transfer Program in Mexico}

PROSPERA-Oportunidades is a CCT program that is directed at poor families in Mexico; its main objective is to break the inter-generational poverty cycle. Since the beginning of its operation (1997), the beneficiary families receive a monthly cash transfer that is conditioned to them sending their children to school and attending health centers to receive preventive care for their children. (DOF 2016; SEDESOL 2008a, 2009, 2017).

The PROSPERA-Oportunidades program is currently the most important anti-poverty program operating in Mexico. Its importance can be seen in the coverage of 6.1 million families, especially in rural areas where 3.5 million households (6 out of every 10) are program beneficiaries and the current budget of around 82.151 billion Mexican Pesos (approximately US\$ 4.6 billion) (DOF 2016). 
With an operating cost of less than 5 cents of a Mexican Peso (approximately US\$ 0.003), ${ }^{1}$ PROSPERA-Oportunidades is one of the most efficient CCT programs worldwide (CONEVAL 2013). Its operating cost can be explained by its inter-institutional coordination. For example, the Ministries for Education and Health provide the physical infrastructure (schools and health centers respectively) that are needed to operate this program on a local level. Various evaluations made of the PROSPERA-Oportunidades program, the majority of which were undertaken within the first 10 years of its implementation, show a positive short-term impact on education and health. ${ }^{2}$ These results will be explained further in the next paragraph.

\section{PROSPERA-Oportunidades Short-Term Program Effects}

Over the 20 years of its implementation, impact measurement of PROSPERA-Oportunidades has shown positive results in the three components focused on the development of human capital: education, health, and nutritional benefits. Yet, these results are based on the independent analysis of program outcomes and does not provide a longitudinal perspective on long-term behavioral changes of beneficiary families and especially after the program participation has been terminated.

While a multitude of academics evaluated the programs short-term impact on the use of healthcare by all household members (Gertler 2000; Hernández and Huerta 2000; Huerta and Martínez 2000; Bautista et al. 2003), only Gutiérrez et al. (2005) focused on a medium-term impact evaluation while Escobar and González de la Rocha (2009) provided a qualitative evaluation. Yet, all of them agreed in that the program had a positive impact on the number of visits to health service facilities by all household members. Another example are maternal deaths and infant mortality that have decreased by 11 and 2\%, respectively (SEDESOL 2010). The health of children less than 6 years of age has improved, and the number of sick days per year has been reduced by $20 \%$ with an average number of 2 days (de la Torre García n.d.).

The same positive short-term program impact was observed for children's health and nutritional status as mentioned by Gertler (2000), Bautista et al. (2003), Behrman and Hoddinott (2000), Huerta and Martínez (2000) and Neufeld et al. (2004). In the same way, data from 2012 shows a decrease of $22 \%$ in chronic child under-nutrition affecting $12 \%$ of the participating infant population (SEDESOL 2014). In the case of anemia, an important decrease was also achieved. This is why, in the same year of reporting, only $25 \%$ of the total infant population presented this disease, compared to 61\% in the year 1999 (SEDESOL 2008b, 2010, 2014).

In contrast to the very positive short-term program results on health and nutrition, the short-term impact on school enrollment has been small as observed by Schultz (1999). Parker (2003) found no impact on primary school enrollment but a positive effect on failure and dropout rates. In the case of educational benefits, the presented results show a positive effect in children's school assistance, especially that of girls who receive a larger sum in secondary and high school (equivalent of 7 th to 12th grade) (SEDESOL 2008b, 2010, 2014, 2016; Behrman et al. 2005; Parker 2003).

Official data exposed previously provides evidence of the positive CCT program effects on specific topics such as children's school enrollment, nutritional levels (especially in small children), and the health conditions of the families participating in the program. Yet, the majority of this data is based on transversal evaluations in one single time dimension. Hence, they do not provide information-and in fact they can hide-on the long-term effects that the above mentioned improvements in health and education have on affecting existing cultural habits of the beneficiary families long-term. The question to be raised is if a change in behavior of the beneficiary families is sufficient to allow them to escape from

1 https://transparencia.info.jalisco.gob.mx/sites/default/files/Costo\%20de\%20operaci\%C3\%B3n\%20y\%20metodolog\% C3\%ADa\%20de\%20evaluaci\%C3\%B3n\%20del\%20Programa\%20Prospera\%202015.pdf.

2 According to public information by the National Council for the Evaluation of Social Policy (CONEVAL), the last public impact evaluation of the PROSPERA-Oportunidades program dates back to the year 2012. http:/ / www.coneval.org.mx/ Evaluacion/Paginas/InformeEvaluacion.aspx (accessed on 28 July 2017). 
poverty. The importance and impact of additional elements, that are strategic in nature and go beyond the neo-liberal understanding of poverty, such as the lack of access to long-term sustainable work opportunities and an adequate salary that allows the participants to satisfy their own and their family's basic needs should be analyzed further (Farrington and Slater 2006; Hall 2008; Handa and Davis 2006; Vizcarra 2002).

In addition, short-term impact evaluations for PROSPERA-Oportunidades (de la Torre García n.d.; Cohen et al. 2006; Bouillon and Tijerina 2006; Bautista et al. 2003; Behrman et al. 2005; Martínez 2012) do not pay sufficient attention to other questions that are included in the design and application of this type of anti-poverty program such as conditionality of cash transfers and its long-term effect.

The experience has been replicated with short-term success in various Latin American countries, such as Bolsa Familia in Brazil, Red de Protección Social in Nicaragua, Familias en Acción in Colombia. Empirical evidence from these three countries, suggests long-term difficulties to retain children in school. In the same manner, all these three Latin American experiences face long-term challenges in relation to families attending preventive health care services (Hall 2008; Rivera et al. 2015; Sánchez 2015; Villatoro 2005). Moreover, Standing (2007) reports that in rural areas of Latin America and throughout regions such as sub-Saharan Africa, conditionality related to health and education are likely to be ineffective because of a lack of schools, health clinics and transport.

Experience from African countries such as Zimbabwe and Malawi has provided evidence that cash transfers can have a positive short-term impact even without conditionality (Nigenda and González-Robledo 2005; Robertson et al. 2013). Hence, there is not enough evidence to determine whether conditionality should or should not be part of a cash transfer program not only in the short-term but especially long-term.

The arguments above presented lead to suggest that, despite the apparent short-term success of these CCT programs, not only in Mexico but also in other Latin American countries, there is still much debate about conditionality as one of the main components in antipoverty program, particularly as a long-term outcome. (Farrington and Slater 2006; Hall 2008; Handa and Davis 2006; Vizcarra 2002; Molyneux 2006).

\section{The Issue of Conditionality}

Conditionality is based on a neo-liberal vision of poverty. In the Latin American context, the neo-liberal approach has led to an inherently paternalistic focus in the government efforts to alleviating poverty, where poverty is perceived as a marginal phenomenon rooted in cultural habits where families do not invest in human capital.

However, from a moral perspective poor families universally accept ensuring the education of children. Their lack of access to school is better explained by other factors, deprived households need to incorporate the youngest family member into the labor market, as a short-term livelihood strategy, to increase household income. In this regard, through conditionality, neo-liberal antipoverty programs assume that deprived families are incapable of knowing what is in their best long-term interest (Standing 2007), rather than focus on other structural causes that are responsible for leading these households into poverty, such as lack of income and inequality.

The conditionality criteria are part of the conceptual design of the PROSPERA-Oportunidades program, and as such they are considered a positive element in promoting the use of public education and health services by poor Mexican families, affecting existing cultural habits long-term. The above issue reinforces the idea of a "contractual agreement" between the Mexican State and the poor families where the former conditions the behavior of the latter (Scott and Marshall 2005; Molyneux 2006). On an operational level, conditionality becomes significant due to the link between the program requisites and the benefits of conditional cash transfers.

If one expects conditionality to have a favorable impact on the internalization of preventive health and education "habits" by the poor families of the country, this type of effect is restricted to the program participants and is therefore not necessarily permanent (or long-term). This type of 
argument will be developed in major detail in the next chapter where the results obtained from a longitudinal analysis with panel data from the MxFLS survey for the respective years of observation (2002, 2005-2006, and 2009-2012) are discussed.

\section{Estimations and Results}

This section is divided into three parts: in the first part, the data set that was used to establish the control and treatment groups is presented. The second part describes the estimation process and the used variables. The third part presents the results and briefly discusses the findings.

\subsection{Data}

The household is defined as a group of people that live together in a physical space, whether they are related or not, who share maintenance costs and prepare their food in the same kitchen (SEDESOL 2008a). In this work, the group of households taken into consideration is chosen from the Mexican Family Life Survey (MxFLS) for the time period from 2002 to 2012.

The MxFLS is a longitudinal, multi-thematic panel survey that, for the very first time, allows analyzing data for over a 10-year time period in Mexico, collecting qualitative and quantitative data of a sample of 35,000 individuals, 8400 households, 16 entities, and 150 communities (UIA, CIDE, Duke University 2016).

The base line for the MxFLS was established in 2002, the second round of data was collected from the same individuals in 2005-2006 with a 90 per cent re-contact rate at the household level, and the third round of data was collected between 2009 and 2012. The data is divided into household- and community-level information. Household information is split into individual and household data whereas the community information refers to data as it relates to schools, health services, and general characteristics of the observed community. It is important to identify the households and their members along the 10-year observation period.

For the empirical analysis, we first differentiated between those households that did and did not receive the conditional cash transfer program PROSPERA-Oportunidades. ${ }^{3}$ We then identified the questions from the MxFLS that would shed some light on the underlying hypothesis that CCT programs such as PROSPERA-Oportunidades in Mexico do indeed have positive short-term effects but lack positive long-term impact. These were related to the characteristics of the people included in the control and treatment groups and information about their children's school attendance and the assistance of health centers for preventive check-ups.

\subsection{Methodology}

In this work, the used process is that of matching (Garrido et al. 2014) under four estimation schemes: nearest neighbor, stratification, kernel, and radius (Becker and Ichino 2002). The objective is to calculate the Average Treatment effect on Treated (ATT) of the PROSPERA-Oportunidades CCT program on the beneficiaries as it relates to school and health service assistance during the time period 2002-2009. To determine the ATT, we first calculated the Propensity Score Matching (PSM), based on the following definition by Rosenbaum and Rubin (1983):

$$
E[D \mid X]=P[D=1 \vee X]
$$

where $D$ is a dummy variable that differentiates between control and treatment groups and $X$ is a matrix that unites a set of variables that characterize both groups. The program effect by means of PSM requires the balancing property, which establishes that the observations with the same Propensity Score will have the same distribution of observed characteristics, independently of whether or not they received treatment. In this way, individuals of the treatment and control groups, who should be

3 It is important to note that during the time period of analysis, this programme was just called Oportunidades. 
similar in their average, are compared-in other words, observations where the difference between its corresponding PSM is minimal in the matching process. Formally, if $N^{T}$ is the number of people in the treatment group, $N^{C}$ the number of people in the control group, and $Y_{i}^{T}, Y_{i}^{C}$ the respective observed results, then the average effect that the treatment has on those treated (ATT) can be shown as follows:

$$
A T T=\frac{1}{N^{T}} \sum_{i \in T}\left[\sum_{i \in T} Y_{i}^{T}-\sum_{i \in T} \sum_{j \in C(i)} w_{i j} Y_{j}^{C}\right]
$$

where $C(i)$ is the set of members of the control group paired with the observation $i$ of the treatment group according to the PSM value $p_{i}$, and $i=1,2, \ldots, T$ and $w_{i j}=1 / N_{i}^{C}$ the weighting according to the nearest neighbor, kernel, radius, or stratification estimation techniques (Becker and Ichino 2002), where $i \in T$ and $j \in C(i)$.

The nearest neighbor procedure associates each $i$ observation, in the treatment group, to the $j$ elements of the control group where the difference between their corresponding (PSM) is minimal. While the stratified estimate adds a comparison interval PSM to associate the control group with the treatment group.

The radius estimator links every element $i$ of the treatment group with the elements $j$ of the control group. The resulting difference of the PSM falls within a radius smaller or equal to $r$. This constant is previously defined and enables to choose the nearest neighbor according to the relative distance that can be observed between both treatment and control groups. In fact, if we want to consider the empirical distribution of the control variables with more detail, we can use the Kernel $\mathrm{K}$ to calculate $w_{i j}$ and to improve the estimation of the ATT:

$$
A T T=\frac{1}{N^{T}} \sum_{i \in T}\left[\sum_{i \in T} Y_{i}^{T}-\sum_{i \in T} \sum_{j \in C(i)} K\left(\frac{p_{i}-p_{j}}{h}\right) Y_{j}^{C}\right]
$$

The main advantage of the Kernel is that it uses all the support from the units of the control group which is not the case for other methods (Balmori 2014).

The number of observations used for the estimation consists of 2347 children between 5 and 15 years of age, representing 1995 observations for the control group and 352 for the treatment group.

In this case, the treatment is determined by the individual who receives support from PROSPERA-Oportunidades in the years 2002, 2005, and 2009, according to the MxFLS. It is important to mention that the survey allows following the same individual along those three observation periods.

The outcomes that we analyzed are school assistance and doctor visits in the three time periods.

To calculate the PSM, the following observed characteristics of the household were considered:

a. The age of the child (age).

b. A dummy variable (gender) with a value of 1 if the person is a boy, zero in all other cases.

c. The index of municipal marginalization according to $\operatorname{CONAPO}^{4}(\mathrm{im})$. This variable is an indicator of social exclusion with the dimensions education, housing, and availability of goods and services. A higher number of the index indicates a lower level of marginalization.

d. A dummy variable (rural) with a value of 1 if the community has less than 2500 inhabitants.

e. Years of schooling of the head of household (educ1).

f. Years of schooling of the spouse of the head of household (educ2).

g. A dummy variable (couple) with a value of 1 if the head of household has a partner that he/she lives with or is married to and zero in all other cases.

4 CONAPO (2012). Index of municipal marginalization. Consejo Nacional de Población. http:/ /www.conapo.gob.mx/es / CONAPO/Indice_de_Marginacion_por_Localidad_2010. 
h. A dummy variable (treatment) with a value of 1 if the individual is supported by the program.

i. A dummy variable (school) with a value of 1 if the individual goes to school during the observation period.

j. A dummy variable (medical) with a value of 1 if the individual takes advantage of preventive medical services and/or vaccination during the observation period.

Table 1 presents descriptive statistics for the variables of the control and treatment groups.

Table 1. Descriptive statistics for the treatment and control groups.

\begin{tabular}{ccccc}
\hline \multirow{2}{*}{ Variable } & \multicolumn{3}{c}{ Treatment } & \multicolumn{2}{c}{ Control } \\
\cline { 2 - 5 } & Mean & Standard Deviation & Mean & Standard Deviation \\
\hline Age & 8.03 & 1.94 & 8.06 & 1.95 \\
Gender & 0.46 & 0.50 & 0.50 & 0.50 \\
Im & -0.14 & 0.90 & -0.94 & 0.84 \\
Rural & 0.90 & 0.30 & 0.44 & 0.50 \\
educ1 & 4.00 & 2.95 & 5.53 & 3.58 \\
educ2 & 3.74 & 3.07 & 4.87 & 3.87 \\
Couple & 0.98 & 0.10 & 0.91 & 0.28 \\
School & 0.88 & 0.31 & 0.93 & 0.24 \\
Medical & 0.14 & 0.35 & 0.14 & 0.34 \\
\hline
\end{tabular}

Source: own elaboration with data from the Mexican Family Life Survey (MxFLS) 2002-2012.

In Table 1 it can be observed that the treatment group, in its majority, consists of rural households with a higher level of marginalization, a lower number of years of schooling of the father and mother, and with a slightly smaller proportion of boys that participate in the PROSPERA-Oportunidades program. Yet, regarding school and health service assistance, similar proportions can be observed, even though a matching procedure, comparing only those individuals with similar observable characteristics, is still missing.

The evidence shown in Table 2 confirms that the program effect on school assistance is positive. According to the Kernel and Stratified ATT estimation methods, the probability increases by $6.1 \%$ and $5.9 \%$, respectively, compared to those that do not participate in the program. This conclusion cannot be drawn for the variable medical assistance. It is important to note that only two of the estimation processes show statistical significance in the short-term and that this conclusion cannot be upheld for the long-term (see Table 3).

Table 2. Estimation of the Average Effect of Treatment on the Treated (ATT) in 2002 (short-term impact).

\begin{tabular}{cccc}
\hline School & ATT & Standard Deviation & $\mathbf{t}$ \\
\hline Nearest neighbor & 0.010 & 0.026 & 0.391 \\
Stratified & $0.061^{* * *}$ & 0.021 & 2.883 \\
Kernel & $0.059^{* * *}$ & 0.020 & 2.967 \\
Radius & 0.014 & 0.060 & 0.234 \\
\hline Medical & ATT & Standard Deviation & $\mathbf{t}$ \\
\hline Nearest neighbor & -0.005 & 0.010 & -0.527 \\
Stratified & -0.003 & 0.006 & -0.483 \\
Kernel & -0.002 & 0.006 & -0.392 \\
Radius & 0.005 & 0.019 & 0.258 \\
\hline
\end{tabular}

Source: own elaboration with data from the MxFLS 2002-2012. ***: 1\% significance level. 
Table 3. Estimation of the ATT in 2002-2012 (long term impact).

\begin{tabular}{cccc}
\hline School & ATT & Standard Deviation & $\mathbf{t}$ \\
\hline Nearest neighbor & -0.020 & 0.028 & -0.713 \\
Stratified & -0.024 & 0.021 & -1.150 \\
Kernel & -0.026 & 0.020 & -1.298 \\
Radius & -0.010 & 0.042 & -0.150 \\
\hline Medical & ATT & Standard Deviation & $\mathbf{t}$ \\
\hline Nearest neighbor & 0.009 & 0.006 & 0.923 \\
Stratified & 0.005 & 0.007 & 0.676 \\
Kernel & 0.002 & 0.007 & 0.246 \\
Radius & -0.002 & 0.026 & -0.074 \\
\hline
\end{tabular}

Source: own elaboration with data from the MxFLS 2002-2012.

In Table 3, the estimation of the ATT is shown for the two outcomes, and under the four classical procedures. It can be observed that the program effect is not significant. This tells us that the probability of a child attending school is not substantially affected by the PROSPERA-Oportunidades program. The result for medical assistance is the same.

In other words, remaining in school or school retention of an individual does not vary substantially under the program for the years 2002, 2005-2006, and 2009-2012. On average, the use of health and educational services is the same for the beneficiaries and for the control group, which suggests the need for evaluating the historical program results with more detail. This result can be compared with the findings pointed out by Martínez (2012) related to his research conducted in urban areas located in north eastern Mexico during the time period 2008-2009, where empirical evidence leads to suggest that conditionality has not had a relevant impact on children's school attendance. This is due to the fact that children's school dropout indicators have been high, since this program first started to be implemented, and in the long-term, the problem persists among the program family recipients.

Yet, there are similar studies for Nicaragua (Rawlings and Rubio 2003), South Africa (Samson and Kaniki 2009) and Zimbawe (Robertson et al. 2013), that found that the probability of assisting school increases with subsidies and/or monetary support granted to conditioned households. In this point, it is worth pointing out that the cited studies cover analysis periods smaller than the time interval 2002-2012 which is the basis of analysis for this document.

The present work develops estimates for a broader period of time and uses longitudinal data for the treatment and control groups. It is also important to point out that impact analysis is usually carried out for households living in extreme poverty. In this study, the MxFLS is used which does not include the states of Guerrero y Chiapas, 2 of the 3 poorest states in Mexico, which is why the conclusions do not only provide information for groups living in extreme poverty but for groups suffering from different types of deprivation due to the fact that the only requirement for constructing the treatment group was that the household was included in the PROSPERA-Oportunidades program.

In addition, as it relates to Mexico, there is evidence for a positive program effect, but only in the short-term. Which means that time periods are shorter in duration than the period of observation 2002-2012 used for the purpose of this study. For example, Schultz (1999) found that the rate of primary school attendance was superior among children living in extreme poverty than among those that live in locations covered by the program. Similarly, Skoufias and Parker (2001) find evidence of a positive impact on school attendance in the year 2000 for the PROSPERA-Oportunidades program for the states Guerrero, Hidalgo, Michoacán, Puebla, Querétaro, San Luis Potosí and Veracruz.

Schady (2006) explains that the difference in short and long-term program impact can be attributed to the sociodemographic household characteristics which means that a positive and significant impact can be expected for households living in extreme poverty where the effect decreases in line with decreasing levels of household poverty. This affirmation can also be found in the study elaborated by Veras et al. (2014). Therefore, a support program such as PROSPERA-Oportunidades would not be recommendable for 
households with medium levels of income, in relative terms and in relation to the community context (Villatoro 2009). Specifically, in this context, Banegas-González and Mora-Salas (2012) conclude that PROSPERA-Oportunidades is not an efficient alternative for reducing the structural vulnerability of poor households or for reducing poverty short-term.

In any case, this opens the door to further investigation on the short- and long-term program impact by taking into account other control variables for the chosen households.

\section{Conclusions}

This research analyzed the effectiveness of conditionality in direct cash transfer payments as a long-term incentive for the use of public services-health and education-among the families participating in PROSPERA-Oportunidades. In order to do this, a longitudinal analysis was conducted with panel data from the MxFLS (Mexican Familiy Life Survey). The Average Effect of Treatment on the Treated (ATT) was estimated with the analysis technique "Propensity Score Matching" for the time period 2002-2012. The results show that the program impact on the demand of health and educational services is relevant in the short-term. Nevertheless, this effect is not maintained in the long-term (see Tables 2 and 3).

When looking at the research results of other authors related to short- and long-term effects of PROGRESA-Oportunidades in Mexico, it becomes apparent that most research is indeed focused on short-term effects and on overall program effects on income poverty rather than on social deprivations such as education and health that have been the basis of this analysis. Authors that have focused on measuring long-term program effects include the following:

Skoufias and McClafferty (2001) found a positive short-term effect of PROGRESA-Oportunidades on income poverty in their analysis of the number of people living in poverty and the depth and severity of poverty between 1997 and 1999. Additional research by Skoufias (2005) shows a positive program effect on school attendance, educational results and health which has been confirmed by other authors such as de Janvry et al. (2006); de Brauw and Hoddinott (2011); Gertler et al. (2012).

Tirado-Alcaraz (2014) analyzed whether PROGRESA-Oportunidades has alleviated rural poverty by creating a balanced panel and applying a regression model. He found that the program positively impacted income poverty due to the fact that the ratio of monthly household income to the food poverty line was higher in the case of program participants over time. Yet, when controlling for additional factors such as age, gender, marital status and education of the head of household, Tirado-Alcaraz (2014) finds that the program effect becomes negative. Therefore, the overall findings of his research indicate mixed program effects on income poverty.

Behrman et al. (2011) focused on analyzing the impact of PROGRESA-Oportunidades on schooling and found that program effects are positive and robust with time. They based their analysis on short and longer differential exposures on longer-run outcomes using treatment and control data from a randomized experiment and a nonexperimental comparison group. They use difference-in-difference estimators and propensity score matching (PSM) methods. In comparison to the findings from this study related to the lack of long-term program effects on schooling based on panel data from the MxFLS, Behrman et al. (2011) combination of experimental and nonexperimental data suggests a consistent and robust positive program effect on schooling. The authors remark that their research is not sufficient to draw conclusions on how improvements in social deprivations such as schooling are linked to income and overall poverty.

As previously shown, there is a debate about the conditionality of direct cash transfers in anti-poverty programs. One of the key arguments is based on the modification of the behavior of participating families in the use of these health and educational services in the long-term. Empirical evidence elaborated in this work shows few significant changes in the behavior of its beneficiaries related to continued (or extended) long-term demand of public services. In consequence and according to the neo-liberal understanding of poverty, the program impact on overall poverty levels is therefore minimal. 
With time, the program can lead to additional costs for the participants (i.e., such as time dedicated to working) and, therefore, the families-and more specifically their children - tend to abandon the program. In other words, if the preferences of the poor are not aligned with the requirements, they tend to reduce their gains in well-being, and for some families (usually those most in need and with specific sociodemographic characteristics) it is difficult to comply.

Yet, the shown results of this work correspond to a specific period of analysis (2002-2012) and are therefore not conclusive, which is why it is recommended to evaluate the program results throughout their entire history with major detail to provide further insight into this type of analysis. In addition, it would be important to focus on other questions that have emerged after 20 years of implementing the CCT program in Mexico. This is the case for the relation between the demand for social services by poor families and the quality of these services, such as structural conditions that deal with this phenomenon through the inclusion and work mobility of boys and girls, and beneficiaries of scholarships granted by these governmental anti-poverty programs.

Finally, currently CCT programs are being subject to review. In Mexico and Latin America, they have grown explosively, but in a disorderly and ineffective way. Therefore, to address the problem of poverty reduction in a longer-term and sustainable manner, perhaps we need to start discussing other social protection alternatives, such as basic income-as the ODS Goal 1 (Target 1.3) proposes. Despite its financial challenges, it be could promising.

Author Contributions: All authors contributed equally to this work.

Conflicts of Interest: The authors declare no conflict of interest.

\section{References}

Alkire, Sabina, Adriana Conconi, Gisela Robles, and Suman Seth. 2015. Multidimensional Poverty Index, Winter 2014/2015: Brief Methodological Note and Results. OPHI Briefing 27; Oxford: Oxford University.

Balmori, José. 2014. The Effect of Oportunidades on Reporting Violence against Women to the Police. In Three Essays on Law and Development in Mexico. Edited by Jose Balmori. New York: Cornell Theses and Dissertations, pp. 1-32. Available online: https:/ / ecommons.cornell.edu/handle/1813/37168 (accessed on 5 January 2018).

Banegas-González, Israel, and Minor Mora-Salas. 2012. Transferencias condicionadas y reducción de la pobreza en México: Entre lo real y lo imaginado. European Review of Latin America and Caribbean Studies 93: 41-60. [CrossRef]

Bautista, Sergio, Sebastián Martınez, Stefano Bertozzi, and Paul Gertler. 2003. Evaluación del Efecto de Oportunidades Sobre la Utilización de Servicios de Salud en el Medio Rural. Cuernavaca: INSP.

Becker, Sascha, and Andrea Ichino. 2002. Estimation of average treatment effects based on propensity scores. The Stata Journal 2: 358-77.

Behrman, Jere, and John Hoddinott. 2000. An Evaluation of the Impact of PROGRESA on Pre-School Child Weight. Washington: International Food Policy Research Institute.

Behrman, Jere, Susan Parker, and Petra Todd. 2005. Impacto de Mediano Plazo del Programa Oportunidades sobre la Educación y el Trabajo de Jóvenes del Medio Rural que Tenían de 9 a 15 años de edad en 1997. In Evaluación Evaluación Externa de Impacto del Programa Oportunidades 2004. Edited by B. Hernández Prado and M. Hernández Ávila. Cuernavaca: Instituto Nacional de Salud Publica, vol. 1.

Behrman, Jere R., Susan W. Parker, and Petra E. Todd. 2011. Do Conditional Cash Transfers for Schooling Generate Lasting Benefits? A Five-Year Followup of PROGRESA/Oportunidades. The Journal of Human Resources 46: 93-122. [CrossRef]

Bouillon, César P., and Luis Tijerina. 2006. Do We Know What Works?A Systematic Review of Impact Evaluations of Social Programs in Latin America and the Caribbean. April 1. Available online: https:/ / publications.iadb. org/handle/11319/2801? locale-attribute=en (accessed on 27 July 2017).

Cohen, Ernesto, Rolando Franco, and Pablo Villoro. 2006. México: El Programa de Desarollo Humano Oportunidades. In Transferencia Con Corresponsabilidad: Una Mirada Latinoamericana. Ciudad de México: FLACSO.

CONAPO. 2012. Index of Municipal Marginalization. Consejo Nacional de Población. Available online: http:/ /www. conapo.gob.mx/es/CONAPO/Indice_de_Marginacion_por_Localidad_2010 (accessed on 20 October 2017). 
CONEVAL. 2013. Consejo Nacional de Evaluación de la Política Social. November 1. Available online: http: / / www.coneval.org.mx/Evaluacion/Paginas/InformeEvaluacion.aspx (accessed on 28 July 2017).

De Brauw, Alan, and John Hoddinott. 2011. Must conditional cash transfer programs be conditioned to be effective? The impact of conditioning transfers on school enrollment in Mexico. Journal of Development Economics 96: 359-70. [CrossRef]

De Janvry, Alain, Frederico Finan, Elisabeth Sadoulet, and Renos Vakis. 2006. Can conditional cash transfer programs serve as safety nets in keeping children at school and from working when exposed to shocks? Journal of Development Economics 79: 349-73. [CrossRef]

De la Torre García, R. n.d.; Evaluación Externa de Impacto del Programa Oportunidades. Versión Final. Ciudad de México: Instituto Nacional de Salud Pública.

DOF. 2016. Reglas de Operación de PROSPERA Programa de Inclusión Social Para el Ejercicio Fiscal 2017 y Nota Aclaratoria. December 29. Available online: https://www.gob.mx/cms/uploads/attachment/file/177672/ Reglas_de_Operaci_n_2017.pdf (accessed on 22 July 2017).

Escobar, Augustin, and Mercedes González de la Rocha. 2009. Girls, Mothers and Poverty Reduction in Mexico: Evaluating Progresa-Oportunidades. In The Gendered Impacts of Liberalization: Towards Embedded Liberalism? Edited by Shahra Razavi. Londres: Routledge, pp. 267-89.

Farrington, John, and Rachel Slater. 2006. Introduction: Cash Transfers: Panacea for Poverty Reduction or Money Down the Drain? Development Policy Review 24: 499-511. [CrossRef]

Garrido, Melissa, Amy S. Kelley, Julia Paris, Katherine Roza, Diane E. Meier, Sean R. Morrison, and Melissa D. Aldridge. 2014. Methods for constructing and assessing propensity scores. Health Services Research 49: 1701-20. [CrossRef] [PubMed]

Gertler, Paul J., Harry Anthony Patrinos, and Marta Rubio-Codino. 2012. Empowering parents to improve education: Evidence from rural Mexico. Journal of Development Economics 99: 68-79. [CrossRef]

Gertler, Paul. 2000. Final Report: The Impact of PROGRESA on Health. Final Report; Washington: International Food Policy Research Institute.

Gutiérrez, Juan Pablo, Gertler Paul, Hernandez-Avila Mauricio, and Bertozzi Stefano. 2005. Impacto de Oportunidades en los Comportamientos de Riesgo de los Adolescentes y en sus Consecuencias Inmediatas: Resultados de Corto Plazo en Zonas Urbana y de Mediano Plazo en Zonas Rurales. In Evaluación Externa de Impacto del Programa Oportunidades 2004: Salud. Cuernavaca: Instituto Nacional de Salud Pública.

Hall, Anthony. 2008. Brazil's Bolsa Familia: A Double-Edged Sword? Development and Change 39: 799-822. [CrossRef]

Handa, Sudhanshu, and Benjamin Davis. 2006. The Experience of Conditional Cash Transfers in Latin America and the Caribbean. Development Policy Review 24: 513-36. [CrossRef]

Hernández, Daniel, and María del Carmen Huerta. 2000. Algunos Aspectos de Salud Reproductiva de la Población Beneficiaria de Progresa. In Evaluación de Resultados del Programa de Educación, Salud, y Alimentación. Washington: International Food Policy Research Institute.

Huerta, María del Carmen, and Homero Martínez. 2000. Evaluación del Impacto de Progresa en el Estado de Nutrición de los Menores de 5 años en Localidades Atendidas por IMSS-Solidaridad. In Evaluación de Resultados del Programa de Educación, Salud, y Alimentación. Washington: International Food Policy Institute.

Largaespada, Carmen. 2006. Capitulo 7 Nicaragua: Nicaragua: Red de Proteccion Social y Sistema de Atención a Crisis. In Transferencia Con Corresponsabilidad: Una Mirada Latinoamericana. Edited by Ernesto Cohen and Rolando Franco. Mexico City: FLACSO-Mexico.

Martínez, Oscar Alfonso. 2012. Efectos de las becas educativas del programa Oportunidades sobre la asistencia escolar. El caso de la zona urbana del noreste de México. Desarrollo y Sociedad 69: 99-131.

Molyneux, Maxine. 2006. Mothers at the Service of the New Poverty Agenda: Progresa/Oportunidades, Mexico's Conditional Transfer Programme. Social Policy \& Administration 40: 425-49.

Neufeld, Lynnette, Daniela Sotres-Álvarez, Paul Gertler, Lizbeth Tolentino Mayo, Jorge Jiménez Ruiz, Lia Fernald, Salvador Villalpando, Teresa Shamah, and Juan A. Rivera Dommarco. 2004. Impacto de Oportunidades en el Crecimiento y Estado Nutricional de Ninos en Zonas Rurales. In Evaluación Externa de Impacto del Programa Oportunidades 2004: Alimentación. Cuernavaca: Instituto Nacional de Salud Pública.

Nigenda, Gustavo, and Luz María González-Robledo. 2005. Lessons Offered by Latin American Cash Transfer Programmes, Mexico's Oportunidades and Nicaragua's SPN. Implications for African Countries. London: Centre for Social and Economic Analysis, Mexican Health Foundation. 
Parker, Susan. 2003. Evaluación del Impacto de Oportunidades Sobre la Inscripción Escolar: Primaria, Secundaria y Media Superior. In Resultados de la Evaluación Externa del Programa de Desarrollo Humano Oportunidades 2002. Mexico City: Secretaría de Desarrollo Social.

Rawlings, Laura, and Gloria Rubio. 2003. Evaluating the Impact of Conditional Cash Transfer Programs: Lessons from Latin America. Policy Research Working Paper No. 3119; Washington, DC: World Bank.

Rivera, Juan, Reynaldo Martorell, Wendy González, Chessa Lutter, Teresa González de Cossío, Rafael Flores-Ayala, Ricardo Uauy, and Hernán Delgado. 2015. Prevención de la desnutrición de la madre y el niño: El componente de nutrición de la Iniciativa Salud Mesoamérica. Salud Pública de México 53: 303-11.

Robertson, Laura, Phyllis Mushati, Jeffrey Eaton, Lovemore Dumba, Gideon Mavise, Jeremiah Makoni, Christina Schumacher, Tom Crea, Roeland Monasch, Lorraine Sherr, and et al. 2013. Effects of unconditional and conditional cash transfers on child health and development in Zimbawe: A cluster-randomised trial. Imperial College London 381: 1283-92.

Rosenbaum, Paul, and Donald Rubin. 1983. The central role of the propensity score in observational studies for causal effects. Biometrika 70: 41-55. [CrossRef]

Samson, Michael, and Sheshangai Kaniki. 2009. Pensiones sociales como seguridad social para el desarrollo de África. Poverty Focus 15: 25-27.

Sánchez, Gilda Charlote. 2015. Evolución del Bienestar de los Nicaragüenses, un Enfoque de Pobreza Multidimensional. Working Paper; La Paz, Bolivia: Fundación ARU.

Schady, Norbert. 2006. Programas de Transferencia en Efectivo Condicionado: Repaso de la Información Disponible. Paper presented at the Tercera Conferencia Internacional Sobre Transferencias en Efectivo Condicionadas, Estambul, Tercera, June 26-30.

Schultz, Paul. 1999. Evidencia preliminar del impacto de Progresa en la inscripción a la escuela en 1997 y 1998. In Evaluación de Resultados del Programa de Educación, Salud y Alimentación. Primeros Avances; Mexico City: Secretaría de Desarrollo Social, pp. 155-79.

Skoufias, Emmanuel, and Susan Parker. 2001. Conditional Cash Transfers and their impact on child work and schooling: Evidence from Progresa in Mexico. Economía 2: 45-86. [CrossRef]

Scott, John, and Gordon Marshall. 2005. A Dictionary of Sociology. Oxford: Oxford University Press.

SEDESOL. 2008a. Acuerdo por el que se Emiten las Reglas de Operación del Programa de Desarrollo Humano Oportunidades; Mexico City: Secretaría de Desarrollo Social.

SEDESOL. 2008b. Oportunidades: Un programa de Resultados; Mexico City: Secretaría de Desarrollo Social.

SEDESOL. 2009. Acuerdo por el que se Emiten las Reglas de Operación del Programa de Desarrollo Humano Oportunidades; Mexico City: Secretaría de Desarrollo Social.

SEDESOL. 2010. Oportunidades: Un programa de Resultados; Mexico City: Secretaría de Desarrollo Social.

SEDESOL. 2014. PROSPERA. Programa de Inclusión Social. Available online: https:/ /www.gob.mx/prospera / es\#documentos (accessed on 16 July 2017).

SEDESOL. 2016. 3er. Informe de Labores 2014-2015. Available online: http:/ /www.sedesol.gob.mx/work/models / SEDESOL/PDF/3ER_INFORME_SEDESOL_web.pdf (accessed on 22 July 2017).

SEDESOL. 2017. 1er. Informe Trimestral 2017. Programas de Subsidio del Ramo Administrativo 20. Available online: http:/ / www.sedesol.gob.mx/work/models/SEDESOL/Transparencia/InformesPresupuestoEjercido/ Primer_Informe_Trimestral_2017.pdf (accessed on 22 July 2017).

Skoufias, Emmanuel. 2005. PROGRESA and Its Impacts on the Welfare of Rural Households in Mexico. Washington: International Food Policy Research Institute.

Skoufias, Emmanuel, and Bonnie McClafferty. 2001. Is PROGRESA Working? Summary of the Results of an Evaluation by IFPRI. Washington: International Food Policy Research Institute.

Standing, Guy. 2007. Conditional Cash Transfers: Why Targeting and Conditionalities Could Fail. Brasília: International Poverty Center for Inclusive Growth.

Standing, Guy. 2008. How Cash Transfers Boost Work and Economic Security. UNDESA Working Paper \#58. New York: UNDESA.

Tirado-Alcaraz, J. Alejandro. 2014. Investments in Human Capital: Long-term Effects of Progresa-Oportunidades on Poverty and Migration in Rural Mexico. Journal of Social Research E Policy 5: 23-37.

UIA, CIDE, Duke University. 2016. Mexican Family Life Survey. March 21. Available online: http:/ /www.ennvihmxfls.org/english/index.html (accessed on 5 April 2018). 
UN. 2015. Sustainable Developmente Goals. 17 Goals to Transform Our World. Available online: http://www.un. org/sustainabledevelopment/poverty/ (accessed on 22 July 2017).

Valencia, Enrique. 2008. Conditional Cash Transfers as Social Policy in Latin America: An Assessment of their Contributions and Limitations. Annual Review of Sociology 34: 475-99. [CrossRef]

Van Parijs, Philippe, and Yannick Vanderborght. 2017. Basic Income a Radical Proposal for a Free Society and a Sane Economy. Cambridge: Harvard University Press.

Veras, Fábio Veras, Rafael Perez, and Rafael Guerreiro. 2014. Evaluating the impact of Brazil's Bolsa Família: Cash Transfer Programs in Comparative Perspective. Latin American Research Review 45: 173-90.

Villatoro, Pablo. 2005. Programas de transferencias monetarias condicionadas: Experiencias en América Latina. Revista de la CEPAL 83: 88-101.

Villatoro, Pablo. 2009. Las TMC en América Latina: Acumulación de capital humano y reducción de la pobreza. Poverty Focus 15: 15-16.

Vizcarra, Ivonne. 2002. Social Welfare of the 1990s in Mexico. The Case of "Marginal" Families in the Mazahua Region. Anthropologica 44: 209-22.

(C) 2018 by the authors. Licensee MDPI, Basel, Switzerland. This article is an open access article distributed under the terms and conditions of the Creative Commons Attribution (CC BY) license (http:/ / creativecommons.org/licenses/by/4.0/). 